\title{
СТАТУС БІЖЕНЦЯ У КОНТЕКСТІ ПРАВОВОї ПОЛІТИКИ ЕС
}

\author{
БОРТНИК Надія Петрівна - доктор юридичних наук, професор, завідувач \\ кафедри адміністративного та інформаційного права Національного університету \\ «Љьвівська політехніка", \\ МАЛЕЦЬ Марта Романівна - асистент кафедри адміністративного та \\ інформаційного права Національного університету «Львівська політехніка»
}

DOI 10.32782/NP.2020.4.25

\begin{abstract}
В статье проводится анализ правовой основъ Европейского Союза, касающейся вопросов предоставления убежища и статуса бежениа. Замечено, что бежениь - это люди, которьие бъили вылнужденъи, в силу различньлх причин расторгнуть все связи со своей этнической родиной. Они не могут больше рассчитьльть на помощь свочх правительств 8 контексте получения необходимого правовой зашить; именно этот аспект отличает беженцев от других категорий мигрантов, в каком бъ сложном положении последние не находились, а также от других людей, которъие нуждаются в гуманитарной помощи. В связи с тем, ито бежениь не имеют непосредственного доступа к правовой и сочиальной защите, международное сообщество въинуждено осуществлять особъе мероприятия с иелью облегчения их исключительного положения.
\end{abstract}

Отмечено тот фбакт, ито мировому сообществу давно понятно, ито существует очевидная взаимосвязь между проблемой беженцев и вопросами прав человека. Нарушение прав человека вълтупают не только одной из главнъгх причин массового ухода, но и исключает возможность добровольной репатриации до тех пор, пока они не прекратятся. Нарушение прав национальных меньшинств и межэтнические конфблкть все чаще становятся причинами и массового въхода, и перемещения населения внутри странъ.

Указано, что «право Европейского Союза» направлено на максимальное содействие решению проблемь беженцев и предоставления убежища тем, кто в нем нуждается.
Ключевые слова: правовая система, структура права, первичное право, вторичное право, система убежища, статус беженцев, третья безопасная страна.

\section{Постановка проблеми}

Ще декілька десятків років тому в західноєвропейських країнах шукали притулку не більше тридцяти тисяч іноземців щорічно. Проте 3 часом у результаті численних громадянських та локальних конфліктів кількість біженців почала швидко зростати. Не бачений раніше економічний розвиток та здешевлення транспорту зробили Західну Европу доступною для мешканців найвіддаленіших місць земної кулі.

Аналіз досліджень проблеми

Варто зауважити, що різноаспектні питання щодо біженців досліджуються фахівцями багатьох спеціальностей: географами, істориками, етнографами, соціологами, юристами, статистиками тощо. На дослідження правового регулювання статусу біженців справили істотний вплив наукові розробки таких західних дослідників, як Г. Гудвін-Гілл, ᄉ. Холборн, Т. Хаммар, російських учених Ж. Зайончковської, В. Потапова, А. Ястребової, а також вітчизняних авторів О. Кузьменко, Е. Аібанової, О. Малиновської, С. Пирожкова, О. Піскуна, І. Прибиткової, Ю. Римаренка, М. Сірант, С. Чеховича, М. Шульги та інших. Залежно від мети та характеру наукового аналізу в межах кожної галузі знань сформувалися специфічні підходи щодо ана- 
лізу питань, тією чи іншою мірою пов'язаних із проблемами біженців, зокрема визначення характеру правової системи країн Европейського Союзу щодо надання статусу біженців.

Метою статті є аналіз правової системи Європейського Союзу, що складається 3 первинного та вторинного права, між якими існує ієрархічна залежність. Показ того, що право Євросоюзу має пріоритет стосовно внутрішнього права держав-учасниць, а деякі його норми мають пряму дію у внутрішніх правопорядках цих держав.

\section{Виклад основного матеріалу}

Насамперед, варто зауважити, що повноцінна інтеграція багаточисленних потоків шукачів притулку у нові суспільства неможлива без належного правового підгрунтя. Таким підгрунтям виступає право Европейського Союзу. Проте, варто одразу наголосити на тому, що ані у доктрині права європейських інтеграційних організацій, ані у документальних джерелах не існує однозначного визначення поняття «право Европейського Союзу». Не менш складним залишається питання щодо його системи. Однак, враховуючи те, що поняття «право Европейського Союзу» $\epsilon$ визначальним у доктрині і використовується у судовій практиці, можна стверджувати, що вже існує більш-менш однозначне розуміння як самого терміна «право Европейського Союзу», так і його змісту.

На нашу думку, право Европейського Союзу можна визначити як сукупність правових норм, які регулюють процеси європейської інтеграції, здійснюваної в межах Европейського Союзу.

Якщо ж аналізувати структуру права Свросоюзу, то загалом важко говорити про якусь ієрархію його норм, однак можна стверджувати, що певна підпорядкованість між нормами право Європейського Союзу все ж існує. Зокрема, це проявляється у тому, що право Свропейського Союзу поділяється на первинне та вторинне.

Первинне право - це норми міжнародних угод, які становлять правову основу для функціонування всіх структур, що формують Евросоюз.
Вторинне право - більш складна підсистема норм, до якої відносять норми, що закріплені в актах органів європейських інтеграційних організацій, а також у міжнародних угодах, які уклали між собою європейські співтовариства та інші суб'єкти міжнародного права. Вторинне право не повинно суперечити первинному, яке $\epsilon$ основою правопорядку Европейського Союзу [1, с.138].

Хоча система права Европейського Союзу постійно розвивається, але вже тепер можна виділити такі їі окремі складові, як галузі та інститути.

До галузей права Євросоюзу належать: сукупність правових норм, які визначають правове становище Европейського Союзу; норми 3 регулювання внутрішнього ринку; норми у галузі сільського господарства; торговельне та комерційне право; право конкуренції; право охорони навколишнього середовища; трудове право; митне право; міграційне право; право щодо державних замовлень; право зовнішніх зносин тощо.

Що ж стосується інститутів права Евросоюзу, то можна говорити про два їх види. По-перше, це інститути, що є загальними для всієї системи права Евросоюзу. До них належать визнання, правонаступництво, відповідальність. По-друге, крім того, у кожній із галузей права Евросоюзу формуються свої інститути, зокрема такі, як свобода пересування товарів, вільного руху людей, свобода економічної діяльності тощо.

На наше переконання, вдосконалення права Євросоюзу було викликане цілком прикладними проблемами, адже якщо у 1984 році у країнах регіону було подано 100 тис. клопотань щодо надання статусу біженця, то вже у 1989 році ця цифра зросла до 320 тис. клопотань [2, с.52]. Згідно з даними Управління Верховного Комісара ООН у справах біженців, кількість біженців, які станом на 2001 рік проживали у західноєвропейських країнах, перевищувала 2 млн. осіб. Усього впродовж 90-х років минулого століття ці країни прийняли близько 5 млн. вимушених мігрантів [3].

Усе це дозволяє говорити про певну кризу європейської системи притулку. Окрім багаторазового збільшення кількості осіб, які клопоталися щодо надання статусу біженця, 
серед іiі ознак були: різке зменшення відсотку визнання заявників біженцями; значне збільшення терміну розгляду клопотань, який інколи тривав роками; суттєве зростання витрат на процедуру визначення статусу i, як наслідок цього, зниження рівня та якості допомоги [4].

Уряди та громадськість більшості країн Европейського Союзу все частіше вбачали у біженцях реальну загрозу внутрішній стабільності. А право притулку сприймалося ними не як одне із основоположних прав людини, позбавленої захисту у себе на батьківщині, а як один із варіантів вирішення гострих життєвих проблем для небажаних іноземців, який необхідно якомога надійніше перекрити. Внаслідок цього зусилля у сфері регулювання імміграційних процесів як на національному, так і на регіональних рівнях, тобто у рамках Европейського Союзу, зосереджувалися переважно на посиленні контролю над в'їздом та боротьбі з нелегальною імміграцією.

Країни, які свого часу ініціювали Конвенцію ООН 1951 р. про біженців, безперечно, не ставили під сумнів основоположні норми міжнародного права. Проте обмеження на шляху набуття статусу біженця встановлювалися ними на всіх етапах розгляду клопотань шукачів притулку. Відповідні зміни було внесено у законодавство майже всіх західноєвропейських країн. У багатьох випадках вони були підтверджені або, навпаки, ініційовані спільними рішеннями Свропейського Союзу, що приймалися у формі рекомендацій і не мали обов'язкової сили, однак суттево впливали на розвиток національних законодавств у цій сфері.

Наприклад, практично у всіх країнах Свропейського Союзу введено прискорену процедуру розгляду, очевидно, необгрунтованих клопотань щодо надання статусу біженця, які не заслуговували будь-якого детального розгляду. 3 цього приводу наприкінці 1992 року міністри у справах міграції Европейського Союзу прийняли спеціальну резолюцію, у якій було чітко сформульовано визначення, очевидно, необгрунтованих клопотань, а також інших категорій справ, які можна розглядати за прискореною процедурою [5]. До них належали клопотання, в яких не було посилань на факти переслідувань за змістом Конвенції 1951 р. і вказані такі мотиви прибуття, як пошук роботи чи кращих умов життя. Окрім того, необгрунтованими вважалися клопотання, які грунтувалися на очевидній неправдивій інформації: заявник видавав себе за іншу людину, використовував фальшиві документи, але наполягав на тому, що вони дійсні, навмисне знищив або викинув документи, подав неправдиві відомості, подав декілька клопотань в одній або різних країнах одночасно тощо.

Разом із наведеною вище резолюцією було прийнято ще дві, в яких запропоновано спільний підхід щодо визначення концепції «третьої безпечної країни» або «безпечної країни походження». У них ішлося про застосування прискорених процедур у тих випадках, коли, перш ніж клопотатися про статус біженця, особа перебувала в іншій безпечній державі, де могла просити притулку, або країна її походження є безпечною, тобто серйозної загрози переслідувань там немає.

У деяких західноєвропейських країнах, наприклад у Німеччині, Фінляндії, Швейцарії, рішеннями виконавчих органів або законодавчої влади затверджуються списки безпечних країн. Критерії їхного визначення досить різні, проте здебільшого безпечними вважаються країни Європейського Союзу, а також ті, що приєдналися до Конвенції 1951 р. і виконують узяті на себе зобов'язання [5].

Щодо визначення так званої третьої безпечної країни або країни першого притулку, що повинна нести відповідальність за розгляд клопотання щодо надання статусу біженця, також існують певні національні відмінності. Так, у Швейцарії, Бельгії, Данії, Норвегії, хоча це поняття і застосовують, проте вважають доцільним те, що людина, яка має родинні чи інші зв'язки з відповідною країною, клопочеться про притулок саме в ній, а не в тій країні, яку вона проїжджала транзитом. Правило третьої безпечної країни, зокрема, не застосовується також у випадку простого транзиту шукача притулку через територію іншої держави. Наприклад, особу, яка перебувала у транзитній зоні аеропорту не вважають такою, що перебувала на території іншої держави. Законодавство деяких країн встановлює термін, у рамках яко- 
го перебування вважається транзитним, до прикладу, у Швейцарії цей термін становить до 20 днів, а у Бельгії - до 3-х місяців.

На відміну від зазначених резолюцій, які носять рекомендаційний характер, Дублінська конвенція 1990 року [6], що набула чинності в 1997 році, є обов'язковою. Підписавши іiі, країни Европейського Союзу погодилися 3 тим, що розгляд прохань шукачів притулку повинна брати на себе та країна, яка дозволила їм в’їзд на свою територію, тобто оформила візу, або ж перша країна в”ізду у випадку нелегального проникнення на територію Свропейського Союзу. Ця Конвенція регулює, таким чином, питання щодо визначення країни, відповідальної за розгляд клопотань, а також має на меті забезпечити більш справедливий розподіл витрат, яких потребує ця процедура.

На наш погляд, необхідність Дублінської конвенції пояснюється тим, що, оскільки умови надання статусу біженця і соціальні гарантії біженців у різних країнах неоднакові, шукачі притулку намагалися звертатися за статусом саме там, де такі умови були найвигіднішими. До того ж, певні особи, звертаючись за статусом біженця по черзі у різних країнах Європейського Союзу, зловживали захистом і продовжували користуватися допомогою на час розгляду клопотання в одній країні, навіть якщо вже отримали відмову в іншій, або навіть у кількох країнах водночас. Тому автоматична передача клопотання для розгляду у першу безпечну країну, куди прибув шукач притулку, є цілком виправданою. Проблема однак полягає у тому, що законодавство більшості європейських країн не вимагає попередньо заручитися згодою цієї країни для прийняття цієї людини і допуску іï до процедури визначення статусу біженця. Окрім цього, не виключено, що депортація може набути ланцюгового характеру аж до країни, з якої шукач притулку прибув і де йому загрожує небезпека, що суперечить основному міжнародно-правовому принципу захисту біженців - невислання.

Загалом, протягом 90-х років ХХ ст. політика країн Європейського Союзу у сфері притулку була досить суперечливою. Бажання обмежити наплив біженців співісну- вало 3 необхідністю збереження та розвитку основоположних для західних демократій принципів. До того ж, влада повинна була рахуватися і з громадськістю, неурядовими організаціями, які активно захищали права людини, у тому числі шукачів притулку. Тому поряд із обмежувальними заходами систематично розроблялися механізми гарантій, які повинні були забезпечити прозорість, об'єктивність і справедливість чинних процедур надання статусу біженця.

Так, одним 3 основних положень Резолюції Ради Европейського Союзу «Про мінімальні гарантії процедур надання притулку» [7] є забезпечення можливостей оскарження та перегляду негативного рішення щодо надання статусу біженця. При цьому подання апеляції повинно призупиняти виконання рішення про депортацію. Треба зазначити, однак, що ця вимога може не поширюватися на клопотання, які розглядаються за прискореною процедурою.

Узагальненню та розвиткові позитивної практики у сфері захисту біженців слугує ще один важливий документ Европейського Союзу - так звана Спільна позиція щодо узгодженого застосування терміну «біженець», яка була вироблена в 1996 році [8]. Цей документ грунтується на тлумаченні терміну «біженець», якого дотримується УВКБ ООН. Надзвичайно важливо, що західноєвропейські країни погодилися із необхідністю міжнародного захисту осіб, яким у випадку повернення на етнічну батьківщину загрожує небезпека через обставини, не враховані у Конвенції 1951 року. Іншими словами, відповідно до національних процедур притулок у країнах Західної Европи може бути надано значно ширшій категорії осіб, ніж це передбачено Конвенцією.

У Спільній позиції зазначено, що переслідування третіми сторонами, тобто недержавними силами, також може розглядатися як факт, що підпадає під дію цієї Конвенції. Окрім того, переслідування як підстава для набуття статусу біженця може мати місце внаслідок громадянської війни або інших внутрішніх чи міжнародних воєнних конфліктів. Особи, які відмовляються від військової служби, та дезертири також можуть вимагати захисту, якщо виконання ними вій- 
ськового обов'язку могло призвести до участі у діях проти людства та людяності.

До того ж, у документі розглядається такий важливий момент процедури, як оцінка доказів переслідувань, що є мотивом прохання щодо надання статусу біженця. Йдеться, зокрема про те, що визнання особи біженцем не залежить від надання формальних доказів. Немає потреби у пошуках детальних підтверджень фактів переслідувань, якщо вони достовірні і відповідають ситуації у країні походження.

Необхідно зауважити, що побоювання, пов'язані 3 наростанням потоків біженців у Західній Європі, та намагання урядів більшості західноєвропейських країн обмежити прибуття біженців на свою територію великою мірою пояснюють, чому сфера міграції та притулку тривалий час залишалася поза межами європейських інтеграційних процесів. Лише після набуття чинності у листопаді 1993 року Маастрихтської угоди відповідні питання було віднесено до юрисдикції Європейського Союзу. Однак, на практиці основні інституції Европейського Союзу мали дуже обмежені повноваження у цій сфері. Рішення приймалися, як правило, у формі необов'язкових рекомендацій і лише за умови повної одностайності.

Амстердамська угода, яка набула чинності 1 травня 1999 року, містить положення, яке дозволяє Европейському Союзу приймати обов'язкове для усіх країн-учасниць законодавство щодо надання притулку. Так, було встановлено п'ятирічний термін, протягом якого питання віз, притулку та імміграції мали бути перенесені з так званої третьої основи Евросоюзу, тобто сфери юстиції та внутрішніх справ до першої основи, яка раніше стосувалася лише економічних питань, i де ширші повноваження мають не уряди окремих держав, представлені у структурі керівництва Свропейського Союзу Радою міністрів, а Еврокомісія, Европарламент та Европейський Суд, що більшою мірою презентують спільні інтереси. Після закінчення перехідного періоду передбачалось, що рішення стосовно візової політики будуть прийматися вже не одноголосно, як раніше, а кваліфікованою більшістю голосів. Аналогічну процедуру було встановлено і для питань надання притулку та імміграції. Країни-учасниці втратили право вносити на розгляд Свропейської Ради законопроєкти, що торкаються сфери притулку. Це стало виключним повноваженням Европейської комісії [9].

У жовтні 1999 року на саміті у Тампере (Фінляндія) голови держав Европейського Союзу виробили політичне підгрунтя реалізації Амстердамської угоди, зокрема у сфері імміграції та надання притулку. Висновки зустрічі у Тампере, хоча і закликали до посилення боротьби 3 нелегальною імміграцією, містили запевнення у цілковитому виконанні Конвенції ООН 1951 р., а також заклик до країн-учасниць беззастережно поважати право на притулок та принцип невислання як передумову реалізації цього права. Це, зокрема, передбачає уникнення звуженого тлумачення норм Конвенції, коли у наданні статусу біженців відмовляють жертвам переслідувань зі сторони недержавних сил, а також збалансоване співвідношення між заходами прикордонного контролю і допуском шукачів притулку, яким необхідний захист, на територію Европейського Союзу.

Зміст цього документа дав змогу провідним організаціям у сфері захисту прав біженців таким, як Європейська рада біженців та вигнанців (ECRE), а також УВКБ ООН оцінити його позитивно, відзначивши, що якщо попередні заяви Европейського Союзу здебільшого концентрували увагу на обмежувальних та контрольних заходах, то у Тампере наголос було зроблено на питаннях надання захисту [10].

На саміті у Тампере були вироблені короткотермінові та довготермінові цілі у сфері формування спільної політики країн Европейського Союзу щодо надання статусу біженців. На найближчу перспективу передбачалося вироблення єдиних уніфікованих підходів, яких окремі країни повинні дотримуватися під час надання статусу біженця відповідно до національного законодавства.

У Тампере також було вирішено запропонувати Европейській Раді погодити спільний режим тимчасового захисту у випадках раптового масового напливу біженців унаслідок військових дій чи природних катаклізмів, а також утворити спільний фонд допомоги біженцям як засіб більш рівномірного розпо- 
ділу витрат у випадку прийняття тією чи іншою країною Свропейського Союзу великих груп людей.

Значну увагу було приділено забезпеченню різностороннього підходу до проблем імміграції, який передбачає, окрім іншого, врахування ситуації з правами людини, політичних і економічних умов у країнах походження іммігрантів та транзитних країнах. Так, протидіяти нелегальній імміграції, передусім торгівлі людьми, передбачалося у тісній співпраці 3 країнами походження та транзиту. Підкреслювалося, на нашу думку цілком справедливо, що таку співпрацю необхідно розвивати також у справі повернення на етнічну батьківщину тих шукачів притулку, яким у силу різних причин було відмовлено у наданні статусу біженця на Заході, насамперед шляхом укладання міждержавних угод [11, с.58].

Підгрунтям спільної, збалансованої політики Європейського Союзу щодо проблем біженців є також Дублінська конвенція та Шенгенські домовленості, укладені країнами EC ще до підписання Амстердамської угоди. Застосування Дублінської конвенції, яка визначає країну, відповідальну за розгляд клопотання шукача притулку, спричинило багато критичних зауважень. Так, представники правозахисних організацій вважають, що вона суттево звузила наявні можливості набуття статусу біженця в країнах Західної Европи. Адже оскільки спільних міждержавних критеріїв надання статусу біженця поки що не існує, переїзди шукачів притулку з однієї країни до іншої відображають реальні відмінності у шансах стати визнаним біженцем. Окрім того, цю Конвенцію критикували також відповідні національні виконавчі органи. Покладаючись на рішення Конвенції передати шукачів притулку до інших країн, вони часто не могли надати вагомих доказів їхнього прибуття саме 3 цієї країни. Пошуки таких доказів інколи перетворювалися на довготривалий і надзвичайно дорогий процес.

\section{Висновки}

Реалізація законодавства країн Европейського Союзу щодо надання статусу біженців дає підстави сподіватися, що це сприяти- ме удосконаленню процедур і підвищенню відповідних стандартів. Адже деклароване об'єднаною Европою створення зони свободи, безпеки і справедливості стосується не тільки власних громадян, а й усіх іноземців, які з різних причин опинилися на цій території. Навіть коли окремі держави намагаються обмежити надання допомоги біженцям, зробити це в умовах поглиблення інтеграції буде набагато важче. Окрім цього, останні документи Свропейського Союзу передбачають і такий інструмент протидії цим намаганням, як Європейський Суд, а також надають вагомі аргументи стосовно захисту прав біженців.

\section{Література}

1. Опришко В.Ф., Омельченко А.В., Фастовець А.С. Право Европейського Союзу. Заг. частина: Підручник. К., 2002. С. 138.

2. Salt J. Current trends in international Migration in Europe. Council of Europe. Strasburg, 1998. P. 52.

3. Refugees and Other of Concern to UNHCR: 1998 Statistical Overview. UNHCR. Geneva, 1998.

4. Report on Asylum Procedures: Overview of Policies and Practices in IGC Participating States. Geneva, 1997. P. 21, 172, 199, 308.

5. Обзор проблем защиты беженцев в Западной Европе: тенденции в области законодательства и позиция УВКБ ООН. УВКБ ООН, Региональное европейское бюро. Европейская серия. 1995. Т. 1, чис. 3. С. 5- 22.

6. Конвенция, определяющая государство, ответственное за рассмотрение заявлений о предоставлении убежища, поданных в одном из государств-членов Европейского Сообщества (Дублинская конвенция). Сборник международнъих правовъгх актов, регулируюших вопросъ мигращии. М.: МОМ, 1994. C. 137 .

7. Резолюция Совета Европейского Союза от 20 июня 1995 года о минимальных гарантиях процедуры предоставления убежища. Сборник международно-правовъх документов и начиональньх законодательньх актов по вопросам беженцев. Минск: Тесей, 2000. C. 171-179.

8. Совместная позиция от 4 марта 1996 года, определенная Советом на основании 


\section{Дискусіі, обговорення, актуально}

\section{АНОТАЦІЯ}

у статті проводиться аналіз правового підгрунтя Европейського Союзу, що стосується питань надання притулку та статусу бiжения. Зауважено, шо біжениі - ие люди, які були змушені в силу різних причин розірвати всі зв'язки зі своєю етнічною батьківщиною. Вони не можуть більше розраховувати на допомогу своїх урядів у контексті отримання необхідного правового захисту; саме ией аспект відрізняе біжениів від іниих категорій мігрантів, у якому б складному становищі останні не знаходилися, а також від інших людей, які потребують гуманітарної допомоги. У зв'язку 3 тим, що біжениі не мають безпосереднього доступу до правового та соціального захисту, який уряди, що нормально бункиіонують повинні надавати своӥм громадянам, міжнародне співтовариство змушене здійснювати особливі заходи з метою полегшення їх виняткового становища.

Наголошено на тому бакті, що світовому співтовариству давно зрозуміло, що існує очевидний взаємозв'язок між проблемою біженицв $i$ питаннями прав людини. Порушення прав людини виступають не тільки однією з головних причин масового виходу, але й виключають можливість добровільної репатріаціӥ до тих пір, поки вони не припиняться. Порушення прав національних меншин $i$ міжетнічні конфлікти все частіше стають причинами $i$ масового виходу, i перемішення населення всередині країни.

Вказано, що «право Европейсъкого Союзу» спрямоване на максимальне сприяння вирішення проблеми біжениів та надання притулку тим, хто його потребує.

Ключові слова: правова система, структура права, первинне право, вторинне право, система притулку, статус біжениів, третя безпечна краӥна.

статьи К.3 Договора об Европейском Союзе по согласованному применению определения термина «беженец» в статье 1 Женевской конвенции от 28 июля 1991 года относительно статуса беженца. Сборник международноправовых документов и национальньхх

\section{SUMMARY}

The article analyzes the legal basis of the European Union regarding asylum and refugee status. It is noted that refugees are people who have been forced to sever all ties with their ethnic homeland for various reasons. They can no longer count on the help of their governments in the context of obtaining the necessary legal protection; it is this aspect that distinguishes refugees from other categories of migrants, no matter how difficult they may be, as well as from other people in need of humanitarian assistance. Due to the fact that refugees do not have direct access to the legal and social protection that well-functioning governments must provide to their citizens, the international community is forced to take special measures to alleviate their plight.

It is emphasized that the world community has long understood that there is a clear link between the refugee problem and human rights issues. Violations of human rights are not only one of the main reasons for mass exodus, but also exclude the possibility of voluntary repatriation until they stop. Violations of the rights of national minorities and interethnic conflicts are increasingly becoming the causes of both mass exodus and displacement within the country.

It is stated that the "law of the European Union» is aimed at maximally helping to solve the refugee problem and provide asylum to those who need it.

Key words: legal system, structure of law, primary law, secondary law, asylum system, refugee status, safe third country.

законодательных актов по вопросам беженцев. Минск: Тесей, 2000. С. 180-191.

9. Analisis of the Treaty of Amsterdam in so far as it relates to asylum policy by the European Council on Refugees and Exiles (ECRE). URL: www.:ecre.org.

10. Baneke P. The right of asylum seekers in the new EU Area of Freedom, Justice and Security. URL: www.:ecre.org.

11. Edminster S. The High Road or the Low Road: The Way Forward to Asylum Harmonization in the European Union. World Refugee Survey 2000. Washington, 2001. P. 58. 